\title{
In vitro free radical scavenging capacity of dimethylglycine sodium salt and its protective ability against oleic acid hydroperoxide-induced oxidative damage in IPEC-J2 cells
}

\author{
KAIWEN BAI ${ }^{1}$, LUYI JIANG ${ }^{2}$, LIGEN ZHANG $^{1}$, YONGWEI ZHAO ${ }^{1}$, YI LU ${ }^{1}$, \\ JINGYA ZHU $^{1}$, JIE CAI $^{1}$, LILI ZHANG $^{1}$ and TIAN WANG ${ }^{1}$ \\ ${ }^{1}$ College of Animal Science and Technology, Nanjing Agricultural University, Nanjing, Jiangsu 210095; \\ ${ }^{2}$ College of Animal Science, Zhejiang University, Hangzhou, Zhejiang 310000, P.R. China
}

Received April 4, 2018; Accepted August 14, 2018

DOI: $10.3892 /$ ijmm.2018.3876

\begin{abstract}
The aim of the present study was to evaluate the in vitro free radical scavenging capacity of dimethylglycine sodium (DMG-Na) and its protective ability against oleic acid hydroperoxide (OAHPx)-induced oxidative damage in IPEC-J2 cells. Initially, the free radical scavenging activities of water-soluble pigments (DMG-Na, betalain, capsanthin and cyanidin-3-rutinoside) were measured and compared with those of Trolox. Subsequently, freshly collected swine blood was mixed with heparin and centrifuged to obtain erythrocytes. In order to induce the free radical chain oxidation in erythrocytes, the aqueous peroxyl radicals were generated by thermal decomposition of 2,2'-azobis(2-amidinopropane) dihydrochloride (AAPH) in oxygen. A $2 \%$ suspension of porcine erythrocytes in PBS buffer were pre-incubated for $30 \mathrm{~min}$ at $37^{\circ} \mathrm{C}$ with DMG-Na $(32 \mu \mathrm{M})$, followed by incubation with or without AAPH $(75 \mathrm{mM})$ for $5 \mathrm{~h}$ with gentle shaking. Additionally, IPEC-J2 cells were randomly assigned to four groups ( $n=6$ per group): Cells treated with phosphate
\end{abstract}

Correspondence to: Professor Tian Wang, College of Animal Science and Technology, Nanjing Agricultural University, 1 Weigang Tongwei Road, Nanjing, Jiangsu 210095, P.R. China

E-mail: tianwangnjau@163.com

Abbreviations: DMG-Na, dimethylglycine sodium salt; OAHPx, oleic acid hydroperoxides; ROS, reactive oxygen species; DPPH, 1,1-diphenyl-2-pierylhydrazy; $\mathrm{ABTS}^{+}, \quad$ 2,2'-azinobis(3-ethylbenzthiazoline-6-sulphonate); $\mathrm{O}_{2}^{-}$, superoxide radical; $\mathrm{H}_{2} \mathrm{O}_{2}$, hydrogen peroxide; FRAP, ferric-reducing antioxidant power; SOD, superoxide dismutase; GSH-Px, glutathione peroxidase; GSH, glutathione; GR, glutathione reductase; MDA, malondialdehyde; MnSOD, manganese superoxide dismutase; GPx, glutathione peroxidase; $\gamma$-GCL, $\gamma$-glutamylcysteine ligase; PC, protein carbonyls; 8-OHdG, 8-hydroxy-2-deoxyguanosine; MMP, mitochondrial membrane potential

Key words: dimethylglycine sodium salt, free radicals scavenging capacity, IPEC-J2 cells, antioxidant capacity, oxidative damage buffered saline (PBS); cells treated with DMG-Na (32 $\mu \mathrm{M})$; cells treated with oleic acid hydroperoxides (OAHPx, $20 \mu \mathrm{M}$; TO group); cells treated with DMG-Na $(32 \mu \mathrm{M})$ followed by OAHPx (20 $\mu \mathrm{M}$; DTO group). The cells were cultured in Dulbecco's modified Eagle's medium, Ham's F-12 mixture, $1.5 \mathrm{mM}$ HEPES, 5\% (v/v) fetal bovine serum, $1 \%(\mathrm{v} / \mathrm{v})$ insulin-transferrin-selenium mixture, $1 \%(\mathrm{v} / \mathrm{v})$ penicillin-streptomycin mixture and $2.5 \mu \mathrm{g} / \mathrm{ml}$ fungizone $\left(37^{\circ} \mathrm{C}, 5 \% \mathrm{CO}_{2}\right)$. The results showed that DMG-Na exerted the strongest free radical scavenging capacity at $0.32 \mathrm{M}$ from $0.08-0.64 \mathrm{M}$, and that it could prevent AAPH-induced porcine erythrocyte hemolysis by increasing its antioxidant capacity $(\mathrm{P}<0.05)$. The results also demonstrated that antioxidant capacity and antioxidant-associated gene expression increased in the DTO group relative to the TO group $(\mathrm{P}<0.05)$, indicating that DMG-Na prevented the OAHPX-induced oxidative damage in IPEC-J2 cells by improving the antioxidant capacity and antioxidant-associated gene expression.

\section{Introduction}

Dimethylglycine sodium (DMG-Na) has the ability to improve cellular antioxidant capacity; thus, treatment with DMG-Na may prevent intracellular oxidative damage by scavenging excess free radicals in cells $(1,2)$. Indeed, previous studies have indicated that DMG can reduce oxidative damage and improve animal growth performance (3). Oxidative damage induced by the imbalance of the antioxidant and free radical generation systems can increase the level of reactive oxygen species (ROS), leading to tissue damage (4). Previous studies have indicated that the generation of free radicals is likely one mechanism that leads to the development of diseases, including cancer and neuronal disorders $(5,6)$. ROS, specifically, are generated along with adenosine triphosphate in the mitochondria (7). The production of excess ROS results in an imbalance in cellular redox states, which leads to a decrease in the mitochondrial membrane potential (MMP) and a disorder in mitochondrial functioning (8). There is a complex system of natural enzymatic and non-enzymatic antioxidants in the human body that defend against oxidative damage caused by free radicals and oxidative materials. Recent studies have 
suggested that dietary supplementation with antioxidants may be beneficial in preventing diseases and improving quality of life (2). Antioxidant enzymes or natural products can reduce oxidative damage via their antioxidation capabilities.

The small intestine is the most important digestive organ, and is the first organ damaged when oxidative stress occurs (9). Previous studies have indicated that the generation of free radicals is one of the main mechanisms that lead to many diseases, including gastrointestinal diseases (4). Lipid peroxidation is one of the major causes of oxidative damage, which can contribute to the development of oxygen radical-related damages via increasing level of ROS. Oxidative stress often leads to serious damage to the gastrointestinal tract; therefore, it was proposed that oxidative stress is associated with the clinical risk of gastrointestinal damage failure $(10,11)$. It has been suggested that dietary supplementation with non-enzymatic antioxidants may be beneficial in preventing diseases and improving quality of life. Few studies have focused on the effects of DMG-Na on the small intestine due to the complexity of designing and developing proper human trials. The use of cell cultures is a valid method to overcome this challenge. Particularly, IPEC-J2 cells, which exhibit the properties of normal intestinal epithelium, have been widely used as a suitable model to simulate the gastrointestinal system (12-14). The present study was designed to evaluate the protective effects of DMG-Na against oxidative damage in IPEC-J2 cells, which would provide a potential solution for the prevention and treatment of intestinal damage via enhancing the antioxidant capacity, increasing the antioxidant-associated gene expression, relieving mitochondrial dysfunction and suppressing apoptosis.

\section{Materials and methods}

Radical scavenging assay. 1,1-diphenyl-2-pierylhydrazy (DPPH) radical scavenging activity was calculated according to the method described by Moon and Shibamoto (15). The absorbance was determined with a spectrophotometer at $517 \mathrm{~nm}$ and the formula is as follows: DPPH radical scavenging activity $(\%)=\left(\mathrm{A}_{\text {control }}-\mathrm{A}_{\text {sample }}\right) / \mathrm{A}_{\text {control }} \mathrm{x} 100$; where $\mathrm{A}_{\text {control }}$ was the absorbance of control and $\mathrm{A}_{\text {sample }}$ was the absorbance of water-soluble pigments (DMG-Na, betalain, capsanthin, and cyanidin-3-rutinoside) or Trolox.

2,2'-Azinobis-(3-ethylbenzthiazoline-6-sulphonate) $\left(A B T S^{+}\right)$ assay. The $\mathrm{ABTS}^{+}$radical scavenging activity was measured according to the method of Siddhuraju and Manian (16). The absorbance was recorded with a spectrophotometer at $534 \mathrm{~nm}$ and the formula is as follows: $\mathrm{ABTS}^{+}$radical scavenging activity $(\%)=\left(\mathrm{A}_{\text {control }}-\mathrm{A}_{\text {sample }}\right) / \mathrm{A}_{\text {control }} \mathrm{x} 100$. Where $\mathrm{A}_{\text {control }}$ was the absorbance of control and $\mathrm{A}_{\text {sample }}$ was the absorbance of water-soluble pigments or Trolox.

Superoxide radical $\left(\mathrm{O}_{2}^{-}\right)$assay. $\mathrm{O}_{2}^{-}$scavenging activity was determined using the method of Chen and Yen (17). The absorbance was determined with a spectrophotometer at $560 \mathrm{~nm}$ and the formula is as follows: $\mathrm{O}_{2}^{-}$scavenging activity $(\%)=$ $\left(\mathrm{A}_{\text {control }}-\mathrm{A}_{\text {sample }}\right) / \mathrm{A}_{\text {control }} \times 100$. Where $\mathrm{A}_{\text {control }}$ was the absorbance of control and $\mathrm{A}_{\text {sample }}$ was the absorbance of water-soluble pigments or Trolox.
Hydrogen peroxide $\left(\mathrm{H}_{2} \mathrm{O}_{2}\right)$ assay. The $\mathrm{H}_{2} \mathrm{O}_{2}$ scavenging activity was performed following the procedure of Zhang et al (18). The absorbance was recorded with a spectrophotometer at $230 \mathrm{~nm}$ and the formula is as follows: $\mathrm{H}_{2} \mathrm{O}_{2}$ scavenging activity $(\%)=$ $\left(\mathrm{A}_{\text {control }}-\mathrm{A}_{\text {sample }}\right) / \mathrm{A}_{\text {control }} \times 100$. Where $\mathrm{A}_{\text {control }}$ was the absorbance of control and $\mathrm{A}_{\text {sample }}$ was the absorbance of water-soluble pigments or Trolox.

Ferric-reducing antioxidant power (FRAP) assay. The ferric reducing antioxidant power of water-soluble pigments or Trolox was measured according to the method described by Benzie and Strain (19). The absorbance at $593 \mathrm{~nm}$ was calculated with a spectrophotometer. The reducing power was expressed as $\mu \mathrm{mol} \mathrm{Fe}(\mathrm{II}) / \mathrm{g}$ fresh weight. A standard curve of $\mathrm{FeSO}_{4} \cdot 7 \mathrm{H}_{2} \mathrm{O}$ was used for calibration.

Assay for hemolysis of porcine erythrocytes. Freshly collected swine blood, obtained from a single genetic line [swine from Yangzhou Fangling Agricultural and Pastoral Co., Ltd. (Yangzhou, China); all procedures were approved by the Institutional Animal Care and Use Committee of Nanjing Agricultural University (Nanjing, China)], was mixed with heparin and then centrifuged at $1,500 \mathrm{x}$ g for $10 \mathrm{~min}$ at $4^{\circ} \mathrm{C}$. Following removal of plasma, erythrocytes were washed three times with cool PBS buffer ( $\mathrm{pH}$ 7.4) and finally resuspended in this PBS buffer. In order to induce the free radical chain oxidation in erythrocytes, the aqueous peroxyl radicals were generated by thermal decomposition of 2,2'-azobis(2-amidinopropane) dihydrochloride (AAPH; an azo compound) in oxygen. Briefly, a $2 \%$ suspension of porcine erythrocytes in PBS buffer were pre-incubated for $30 \mathrm{~min}$ at $37^{\circ} \mathrm{C}$ with DMG-Na $(32 \mu \mathrm{M})$, followed by incubation with or without AAPH $(75 \mathrm{mM})$ for $5 \mathrm{~h}$ with gentle shaking. Hemolysis of erythrocytes was determined spectrophotometrically as described by Magalhães et al (20). The hemolysis percentage (\%) was calculated using the formula: Absorbance of supernatant/complete hemolysis x100.

Measurement of erythrocyte antioxidant activity and ROS level. Following repeated sonication (three times), superoxide dismutase (SOD; cat. no. A001-2-1), glutathione peroxidase (GSH-Px; cat. no. A005), glutathione (GSH; cat. no. A006-1) activity and malondialdehyde (MDA; cat. no. A003-4) level in erythrocytes were measured using the corresponding kits (Nanjing Jiancheng Institute of Bioengineering, Nanjing, China) $(21,22)$. The ROS level was detected using a ROS assay kit (cat. no. E004; Nanjing Jiancheng Institute of Bioengineering) (23).

Experimental design of IPEC-J2 cells. DMG-Na was obtained from Qilu Sheng Hua Pharmaceutical Co., Ltd. (Jinan, China). All other chemicals were commercially available and of reagent grade. The non-transformed intestinal cell line IPEC-J2 (Leibniz-Institut DSMZ-Deutsche Sammlung von Mikroorganismen und Zellkulturen $\mathrm{GmbH}$, Braunschweig, Germany) was derived from the jejunum, and cultured as described previously (12). Namely, the IPEC-J2 cells were cultured in Dulbecco's modified Eagle medium, Ham's F-12 mixture, 1.5 mM HEPES, 5\% (v/v) fetal bovine serum, $1 \%(\mathrm{v} / \mathrm{v})$ insulin-transferrin-selenium mixture, $1 \%(\mathrm{v} / \mathrm{v})$ penicillin-streptomycin mixture and $2.5 \mu \mathrm{g} / \mathrm{ml}$ fungizone (Invitrogen; Thermo Fisher Scientific, Inc., Waltham, MA, 
Table I. Primer sequences used for reverse transcription-quantitative polymerase chain reaction.

\begin{tabular}{|c|c|c|}
\hline Gene & Sequence $\left(5^{\prime}-3^{\prime}\right)$ & GenBank accession number \\
\hline$\beta$-actin & $\begin{array}{l}\text { Forward: CTGTCCCTGTATGCCTCTG } \\
\text { Reverse: ATGTCACGCACGATTTCC }\end{array}$ & NM_007393.3 \\
\hline$N r f 2$ & $\begin{array}{l}\text { Forward: GATGTCACCCTGCCCTTAG } \\
\text { Reverse: CTGCCACCATGTTATTCC }\end{array}$ & NM_205117.1 \\
\hline $\mathrm{HOl}$ & $\begin{array}{l}\text { Forward: GGTCCCGAATGAATGCCCTTG } \\
\text { Reverse: ACCGTTCTCCTGGCTCTTGG }\end{array}$ & HM237181.1 \\
\hline$C u / Z n S O D$ & $\begin{array}{l}\text { Forward: CCGGCTTGTCTGATGGAGAT } \\
\text { Reverse: TGCATCTTTTGGTCCACCGT }\end{array}$ & NM_205064.1 \\
\hline$G S H-P x$ & $\begin{array}{l}\text { Forward: GACCAACCCGCAGTACATCA } \\
\text { Reverse: GAGGTGCGGGCTTTCCTTTA }\end{array}$ & NM_001277853.1 \\
\hline$M n S O D$ & $\begin{array}{l}\text { Forward: AGGAGGGGAGCCTAAAGGAGA } \\
\text { Reverse: CCAGCAATGGAATGAGACCTG }\end{array}$ & NM_204211.1 \\
\hline Sirt1 & $\begin{array}{l}\text { Forward: TGCAGACGTGGTAATGTCCAAAC } \\
\text { Reverse: ACATCTTGGCAGTATTTGTGGTGAA }\end{array}$ & NM_019812.2 \\
\hline$\gamma-G C L c$ & $\begin{array}{l}\text { Forward: TGCGGTTCTGCACAAAATGG } \\
\text { Reverse: TGCTGTGCGATGAATTCCCT }\end{array}$ & XM_419910.3 \\
\hline$\gamma-G C L m$ & $\begin{array}{l}\text { Forward: CCAGAACGTCAAAGCACACG } \\
\text { Reverse: TCCTCCCATCCCCCAGAAAT }\end{array}$ & NM_001007953.1 \\
\hline $\operatorname{Tr} x 2$ & $\begin{array}{l}\text { Forward: AGTACGAGGTGTCAGCAGTG } \\
\text { Reverse: CACACGTTGTGAGCAGGAAG }\end{array}$ & NM_001031410.1 \\
\hline $\operatorname{Tr} x-R 2$ & $\begin{array}{l}\text { Forward: CCGGGTCCCTGACATCAAA } \\
\text { Reverse: TAGCTTCGCTGGCATCAACA }\end{array}$ & NM_001122691.1 \\
\hline $\operatorname{Prx3}$ & $\begin{array}{l}\text { Forward: ACCTCGTGCTCTTCTTCTACC } \\
\text { Reverse: ACCACCTCGCAGTTCACATC }\end{array}$ & XM_004942320.1 \\
\hline$O C L N$ & $\begin{array}{l}\text { Forward: CCGTAACCCCGAGTTGGAT } \\
\text { Reverse: ATTGAGGCGGTCGTTGATG }\end{array}$ & NM_205128.1 \\
\hline CLDN2 & $\begin{array}{l}\text { Forward: CCTGCTCACCCTCATTGGAG } \\
\text { Reverse: GCTGAACTCACTCTTGGGCT }\end{array}$ & NM_001277622.1 \\
\hline$C L D N 3$ & $\begin{array}{l}\text { Forward: CCCGTCCCGTTGTTGTTTTG } \\
\text { Reverse: CCCCTTCAACCTTCCCGAAA }\end{array}$ & NM_204202.1 \\
\hline $\mathrm{ZO1}$ & $\begin{array}{l}\text { Forward: TGTAGCCACAGCAAGAGGTG } \\
\text { Reverse: CTGGAATGGCTCCTTGTGGT }\end{array}$ & XM_413773.4 \\
\hline
\end{tabular}

Nrf2, nuclear factor erythroid 2-related factor 2; HO1, heme oxygenase 1; Cu/ZnSOD, copper and zinc superoxide dismutase; GSH-Px, glutathione peroxidase; MnSOD, manganese superoxide dismutase; Sirt1, sirtuin $1 ; \gamma$-GCLc, $\gamma$-glutamylcysteine ligase c; $\gamma$-GCLm, $\gamma$-glutamylcysteine ligase $\mathrm{m}$; Trx2, thioredoxin 2; Trx-R2, thioredoxin reductase 2; Prx3, peroxiredoxin 3; OCLN, occludin; CLDN2, claudin 2; CLDN3, claudin 3; ZO1, zonula occludens-1.

USA) $\left(37^{\circ} \mathrm{C}, 5 \% \mathrm{CO}_{2}\right)$. Cells were harvested by scraping them into $200 \mathrm{ml}$ sodium chloride-tris-ethylenediaminetetraacetic acid (EDTA) buffer (250 mM sucrose, $3.59 \mathrm{mM}$ Trizma ${ }^{\circledR}$-base, $16.4 \mathrm{mM}$ tris- $\mathrm{HCl}, 2 \mathrm{mM}$ EDTA and $40 \mathrm{mM} \mathrm{KCl}$ ). Subsequently, cells were lysed by sonication at $40 \%$ amplitude for $10 \mathrm{sec}$ (three times) and centrifuged at $600 \mathrm{x} \mathrm{g}$ for $10 \mathrm{~min}$ at $4^{\circ} \mathrm{C}$ to remove cell debris.

Oxidative damage was induced by exposing IPEC-J2 cells to $20 \mu \mathrm{M}$ oleic acid hydroperoxides (OAHPx) in lipopolysaccharide, supplemented with $1 \%$ L-glutamine and $1 \%$ non-essential amino acids on the 4th day of culturing when confluency had been reached $(24,25)$. IPEC-J2 cells were randomly assigned to four groups ( $n=6$ per group): i) Cells treated with PBS (T); ii) cells treated with $32 \mu \mathrm{M}$ DMG-Na (TD); iii) cells treated with
$20 \mu \mathrm{M}$ OAHPx (TO); iv) cells treated with $32 \mu \mathrm{M}$ DMG-Na followed by $20 \mu \mathrm{M}$ OAHPx (DTO).

Culture medium was removed at $24 \mathrm{~h}$, and the cells were harvested via brief trypsinization following washing with PBS. Cell suspensions were then centrifuged at $200 \mathrm{x} \mathrm{g}$ for $5 \mathrm{~min}$ and washed with PBS, the cell supernatant was discarded, and the cell pellets were re-suspended in PBS on ice. Cells were lysed using a mini-bead beater for $10 \mathrm{sec}$ at 2,800 $\mathrm{x}$, and the cell lysates were obtained via centrifugation at $14,000 \mathrm{x} \mathrm{g}$ for $10 \min$ at $4^{\circ} \mathrm{C}$.

Assay for cell viability of IPEC-J2 cells. The cells were pre-treated with or without DMG-Na (8-56 $\mu \mathrm{M})$ overnight for $18 \mathrm{~h}$. Neutral red dye (Janssen Pharmaceutica NV, Beerse, 
Belgium) was prepared as a $0.1 \%(\mathrm{w} / \mathrm{v})$ stock solution and diluted 1/10 with washing buffer. After removing the culture medium, $100 \mu \mathrm{l}$ washing buffer plus $50 \mu 10.01 \%$ (w/v) neutral red dye was added to each well, and incubated for $2 \mathrm{~h}\left(37^{\circ} \mathrm{C}, 5 \%\right.$ $\mathrm{CO}_{2}$ ). Afterwards, the cells were washed twice with PBS. The neutral red dye is re- tained in lysosomes of living cells (26). This dye was then extracted from the cells using $100 \mu 150 \%$ (v/v) ethanol solution (in $0.05 \mathrm{M} \mathrm{NaH}_{2} \mathrm{PO}_{4}$ ). The absorbance was measured at $550 \mathrm{~nm}$ using a spectrophotometer (Table II).

Antioxidant capacity assay. The culture supernatants and cell lysate of IPEC-J2 cells at $24 \mathrm{~h}$ were obtained to measure the activity SOD (cat. no. A001-2-1), GSH-Px (cat. no. A005), GSH (cat. no. A006-1) and glutathione reductase (GR; cat. no. A062) using their corresponding assay kits (Nanjing Jiancheng Institute of Bioengineering, Nanjing, China) $(21,22)$.

Assay for mitochondrial isolation. The mitochondria were prepared according to the method described previously by Tang et al (27). Mitochondria were lysed and protein concentration was measured using an BCA assay kit (cat. no. A045-3; Nanjing Jiancheng Institute of Bioengineering) (27).

Mitochondrial antioxidant capacity assay. Manganese superoxide dismutase (MnSOD; cat. no. A001-2-1), GSH-Px (cat. no. A005), GSH (cat. no. A006-1), GR (cat. no. A062), $\gamma$-glutamylcysteine ligase ( $\gamma$-GCL; cat. no. A120) activity, and protein concentration (BCA assay kit; cat. no. A045-4) of mitochondria were calculated using their corresponding assay kits (Nanjing Jiancheng Institute of Bioengineering) $(21,28,29)$.

Assay for lipid peroxidation, protein oxidation and 8-hydroxy-2-deoxyguanosine assay. Lipid peroxidation, expressed as MDA concentration, was determined using an MDA assay kit (cat. no. A003-4; Nanjing Jiancheng Bioengineering Institute) according to the instructions of the manufacturer. The results were expressed in nmol/100 mg protein. Protein oxidation of mitochondria was expressed as the concentration of protein carbonyls (PC), which was calculated according to the method described previously (30), and the results were presented in $\mathrm{nmol} / \mathrm{mg}$ protein. The content of 8-hydroxy-2-deoxyguanosine (8-OhdG) in mitochondria was measured using an ELISA assay kit (cat. no. H165; Nanjing Jiancheng Institute of Bioengineering) and the results were presented as ng/mg protein.

Assay for ROS, MMP and cell apoptosis. The ROS level was detected using a ROS assay kit (cat. no. E004; Nanjing Jiancheng Institute of Bioengineering) (23). Briefly, the mitochondria were incubated with dichlorodihydrofluorescein diacetate (DCFH-DA; $10 \mu \mathrm{M}$ ) and DNA stain Hoechst 33342 $(10 \mathrm{mmol} / \mathrm{l})$ at $37^{\circ} \mathrm{C}$ for $30 \mathrm{~min}$. Then the DCFH fluorescence of the mitochondria was measured at an emission wavelength of $530 \mathrm{~nm}$ and an excitation wavelength of $485 \mathrm{~nm}$ with a fluorescence reader (FACS Aria III; BD Biosciences, Franklin Lakes, NJ, USA). The results were expressed as the mean DCFH-DA fluorescence intensity over that of the control.

The MMP level was calculated according to a method described previously (31). In brief, the mitochondria were loaded with $1 \mathrm{X} \mathrm{JC}-1$ dye at $37^{\circ} \mathrm{C}$ for $20 \mathrm{~min}$, and then
Table II. Cell viability of IPEC-J2 cells.

\begin{tabular}{cr}
\hline DMG-Na $(\mu \mathrm{M})$ & Cell viability $(\%)$ \\
\hline 0 & $100.00 \pm 2.17$ \\
8 & $98.35 \pm 2.54$ \\
16 & $98.32 \pm 3.28$ \\
24 & $98.44 \pm 2.65$ \\
32 & $99.07 \pm 3.02$ \\
40 & $97.24 \pm 3.87$ \\
48 & $97.57 \pm 3.51$ \\
56 & $97.33 \pm 2.79$
\end{tabular}

The experiment was repeated three times, and six repetitions per group. Values are presented as the mean \pm standard error. The values of $0 \mu \mathrm{M}$ DMG-Na group was as to $100 \%$ viability. DMG-Na, dimethylglycine sodium salt.

analyzed, after washing, by flow cytometry (FACS Aria III). The MMP was calculated as the increase in ratio of green and red fluorescence. When the MMP levels are low, JC-1 exists mainly as a monomer, which emits green fluorescence (excitation wavelength of $490 \mathrm{~nm}$ and emission wavelength of $540 \mathrm{~nm}$ ). However, when the MMP levels are high, JC-1 exists mainly as a polymer, which emits red fluorescence (excitation wavelength of $525 \mathrm{~nm}$ and emission wavelength of $590 \mathrm{~nm}$ ). The results were calculated in triplicate as the ratio of the fluorescence of aggregates (red) to that of the monomers (green).

Phosphatidylserine exposure on the outer leaflet of the cell membrane was measured using an Alexa Fluor ${ }^{\circledR} 488$ Annexin V/Dead Cell Apoptosis kit (Thermo Fisher Scientific, Inc.) according to the manufacturer's instructions (16). Briefly, following the preincubation of AAPH and DMG-Na, the cells were washed twice with cool PBS buffer ( $\mathrm{pH}=7.4$, containing $150 \mathrm{mM} \mathrm{NaCl}, 1.9 \mathrm{mM} \mathrm{Na}_{2} \mathrm{HPO}_{4}$ and $8.1 \mathrm{mM} \mathrm{NaH}_{2} \mathrm{PO}_{4}$ ) and resuspended (2\% suspension) in $1 \mathrm{X}$ Annexin-binding buffer. Then, the cell density was determined and diluted in $1 \mathrm{X}$ Annexin-binding buffer to $\sim 1 \times 10^{6}$ cells $/ \mathrm{ml}$. A sufficient volume of the above cell suspension was stained with Annexin V-fluorescein isothiocyanate and propidium iodide (1:9 dilution) staining solution in dark for $15 \mathrm{~min}$ at room temperature. After incubation, the forward scatter of cells was determined, and Annexin V fluorescence intensity was measured in FL-1 with $488 \mathrm{~nm}$ excitation wavelength and $530 \mathrm{~nm}$ emission wavelength on a FACS caliber (BD Biosciences).

Reverse transcription-quantitative polymerase chain reaction $(R T-q P C R)$ assay. Total RNA was obtained from the cells using TRIzol reagent (Invitrogen; Thermo Fisher Scientific, Inc.) and then reverse-transcribed using a commercial kit (Perfect Real Time, SYBR ${ }^{\circledR}$ PrimeScript $^{\mathrm{TM}}$; Thermo Fisher Scientific, Inc.) following the instructions of the manufacturer. The gene expression levels were quantified via qPCR, using SYBR1 Premix Ex Taq II (Tli RNaseH Plus; Thermo Fisher Scientific, Inc.) and an ABI 7300 Fast Real-Time PCR detection system (Applied Biosystems; Thermo Fisher Scientific, Inc.). The SYBR-Green PCR reaction mixture consisted of $10 \mu 1$ SYBR1 Premix Ex Taq ( $\mathrm{X}), 0.4 \mu$ l forward and reverse 

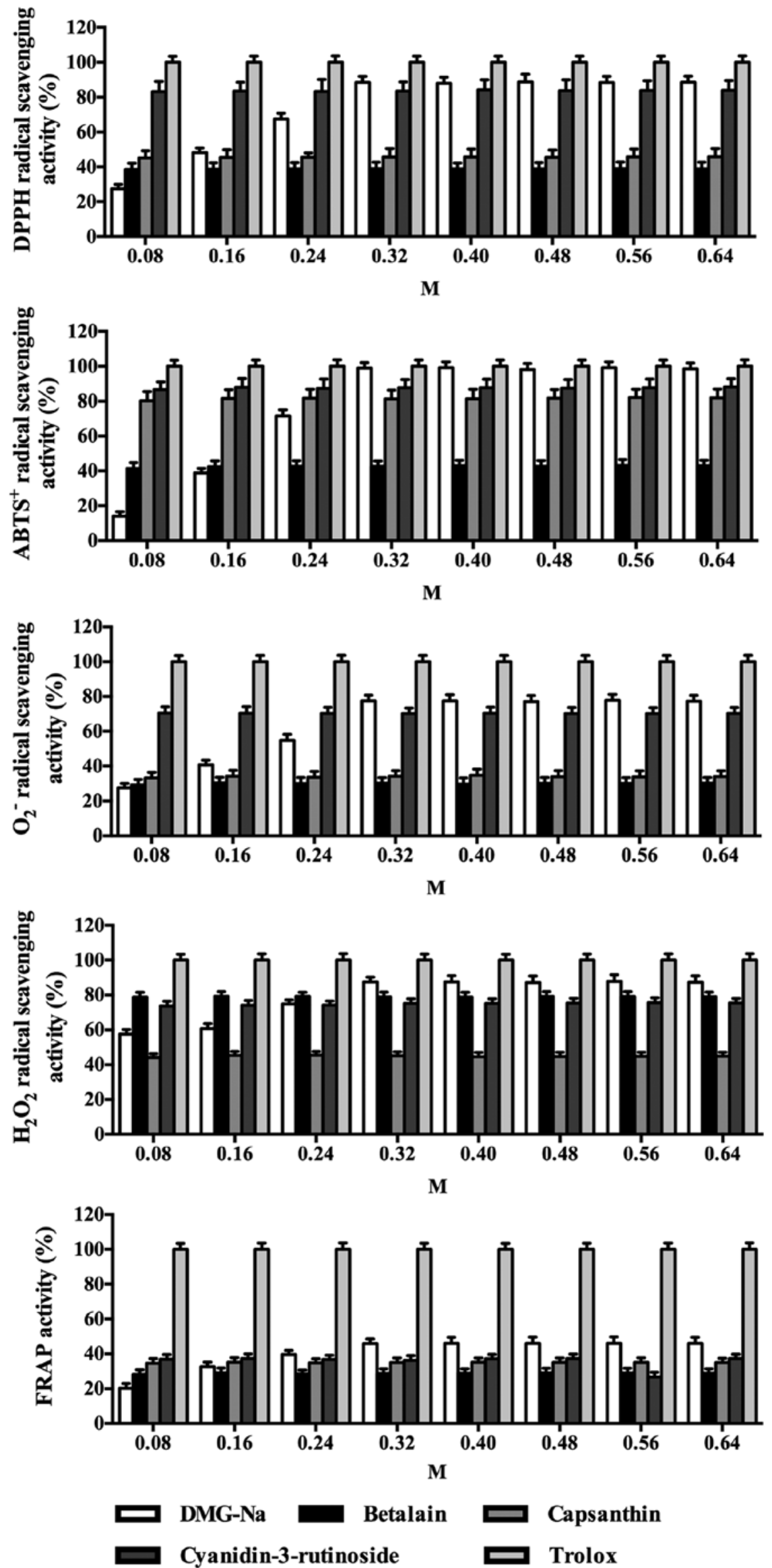

Figure 1. Free radical scavenging capacity of DMG-Na. DPPH, ABTS ${ }^{+}, \mathrm{O}_{2}^{-}$and $\mathrm{H}_{2} \mathrm{O}_{2}$ radical scavenging activity, and FRAP activity were measured. The values of Trolox are set to $100 \%$. The experiment was repeated three times, and six repetitions per group. Values are presented as the mean \pm standard error. DPPH, 1,1-diphenyl-2-pierylhydrazy; $\mathrm{ABTS}^{+}, 2,2^{\prime}$-azinobis-(3-ethylbenzthiazoline-6-sulphonate); $\mathrm{O}_{2}^{-}$, superoxide radical; $\mathrm{H}_{2} \mathrm{O}_{2}$, hydrogen peroxide; $\mathrm{FRAP}^{-}$ ferric-reducing antioxidant power; DMG-Na, dimethylglycine sodium salt. 

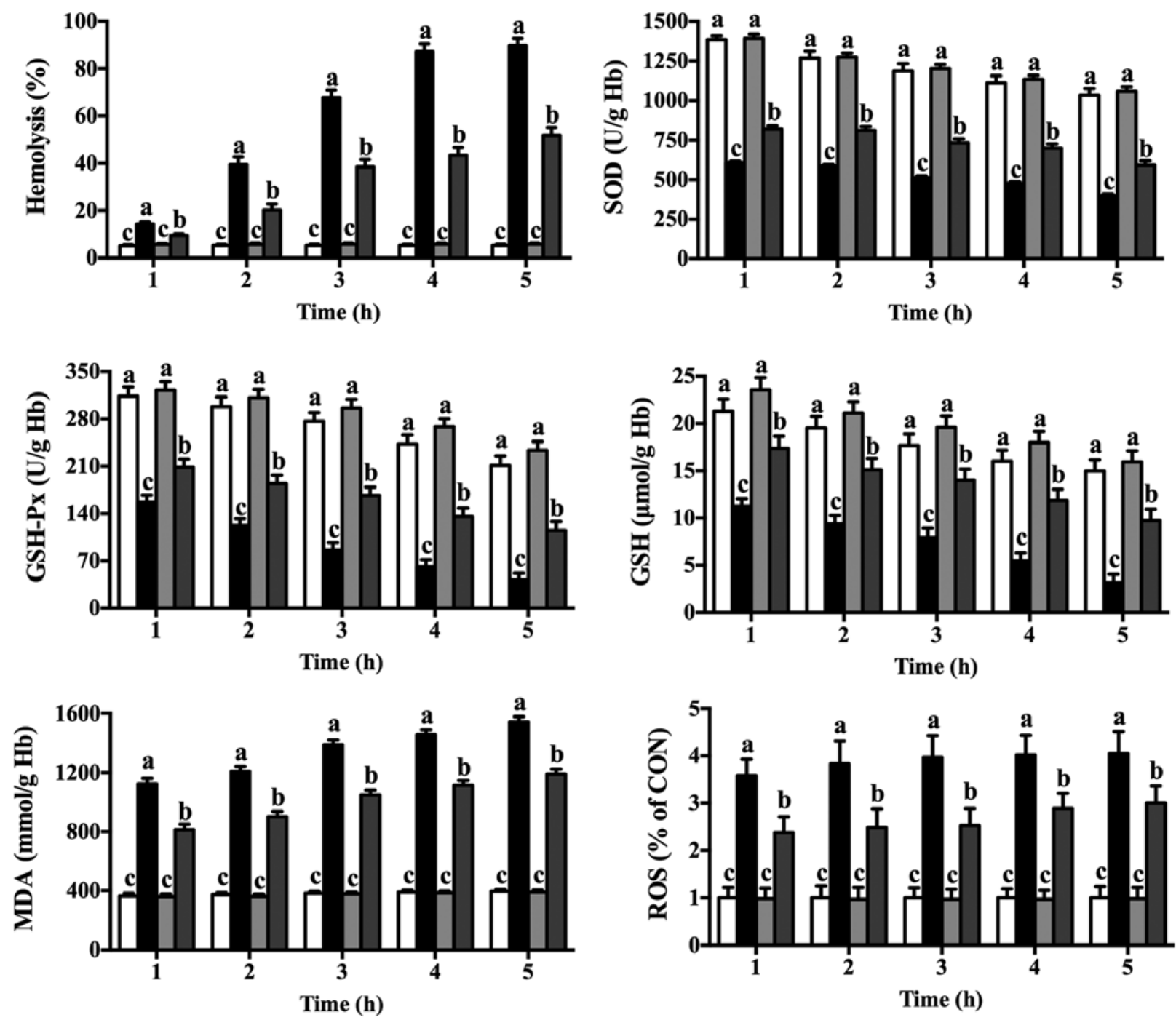

CON $\square$ CON+AAPH $\square$ DMG-Na $\square$ DMG-Na+AAPH

Figure 2. Effects of DMG-Na on the hemolysis, antioxidant capacity and ROS level of AAPH-induced porcine erythrocytes. The experiment was repeated three times, and six repetitions per group. Values are presented as the mean \pm standard error. Groups with different letters were significantly different to each other $(\mathrm{P}<0.05)$. SOD, superoxide dismutase; GSH-Px, glutathione peroxidase; GSH, glutathione; MDA, malondialdehyde; ROS, reactive oxygen species.

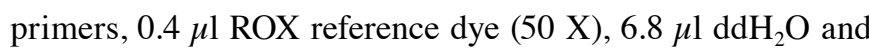
$2 \mu \mathrm{l}$ cDNA template. The cycling conditions were as follows: Pre-run at $95^{\circ} \mathrm{C}$ for $30 \mathrm{sec}, 40$ cycles of denaturation at $95^{\circ} \mathrm{C}$ for $5 \mathrm{sec}$, followed by a $60^{\circ} \mathrm{C}$ annealing step for $30 \mathrm{sec}$. Each sample was run in triplicate. The fold-expression of each gene (Table I) was calculated according to the $2^{-\Delta \Delta \mathrm{Cq}}$ method (32), in which $\beta$-actin was used as an internal standard.

Western blotting. Antibodies against nuclear factor erythroid 2 like 2 (Nrf2), heme oxygenase 1 (HO1) and sirtuin 1 (Sirt1) were purchased from Cell Signaling Technology, Inc. (Danvers, MA, USA). Cells were lysed using Laemmli sample buffer [2\% SDS, $62 \mathrm{mM}$ Tris, 10\% glycerol, 5\% $\beta$-mercaptoethanol, $0.005 \%$ bromphenol blue ( $\mathrm{pH}$ 6.8)] The cellular protein content was measured using a bicinchoninic protein assay kit (Beyotime Institute of Biotechnology, Haimen, China). For western blotting analysis, $50 \mu \mathrm{g}$ protein from each sample was subjected to SDS-PAGE (10\%). Following electrophoresis, the separated proteins were transferred to polyvinylidene difluoride membranes, which were blocked with blocking buffer (5\% nonfat dry milk) for $12 \mathrm{~h}$ at $4^{\circ} \mathrm{C}$. The membranes were then probed with an appropriate primary antibody for $10 \mathrm{~h}$ at $4^{\circ} \mathrm{C}$ [Nrf2 (cat. no. 12721; 1:1,000), HO1 (cat. no. 82206; 1:1,000), Sirt1 (cat. no. 9475; 1:1,000), and $\beta$-actin (cat. no. 4970;1:1,000), respectively] and a secondary antibody for $2 \mathrm{~h}$ at $4^{\circ} \mathrm{C}$ [goat-anti-rabbit secondary antibody $(1: 1,000)$ ] purchased from Cell Signaling Technology, Inc. The blots were detected using enhanced chemiluminescence reagents (ECL-Kit; Beyotime Institute of Biotechnology, Haimen, China) followed by autoradiography. Images of the membranes were taken using a Luminescent Image Analyzer-4000 system (Fujifilm, Tokyo, Japan) and quantified with ImageJ $1.42 \mathrm{q}$ software (National Institutes of Health, Bethesda, MD, USA).

Statistical analysis. All the data were statistically analyzed by one-way analysis of variance procedure of Statistical Analysis System (SAS 2003, v. 9.1; SAS Institute, Inc., Cary, NC, USA). This was followed by the Tukey's test, when significant differences were found. Experiments were repeated three times, and the sample size was six. The data are expressed as 

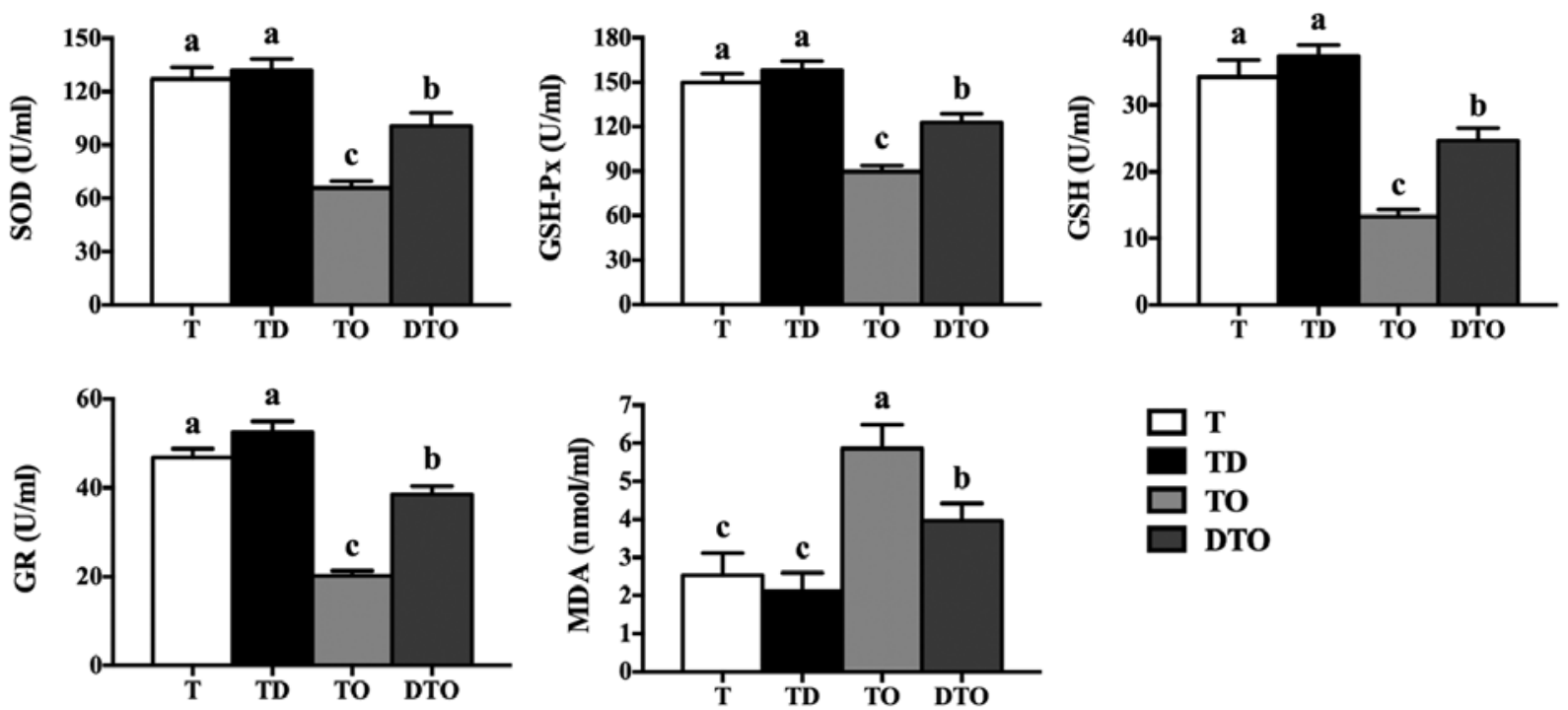

Figure 3. Effects of DMG-Na on the antioxidant capacity of OAHPx-damaged IPEC-J2 cells culture supernatants. The experiment was repeated three times, and six repetitions per group. Values are presented as the mean \pm standard error. Groups with different letters were significantly different to each other (P<0.05). OAHPx, oleic acid hydroperoxides; T, PBS group; TD, $32 \mu \mathrm{M}$ DMG-Na; TO, $20 \mu \mathrm{M}$ OAHPx; DTO, $32 \mu \mathrm{M}$ DMG-Na followed by $20 \mu \mathrm{M}$ OAHPx; SOD, superoxide dismutase; GSH-Px, glutathione peroxidase; GSH, glutathione; GR, glutathione reductase; MDA, malondialdehyde.
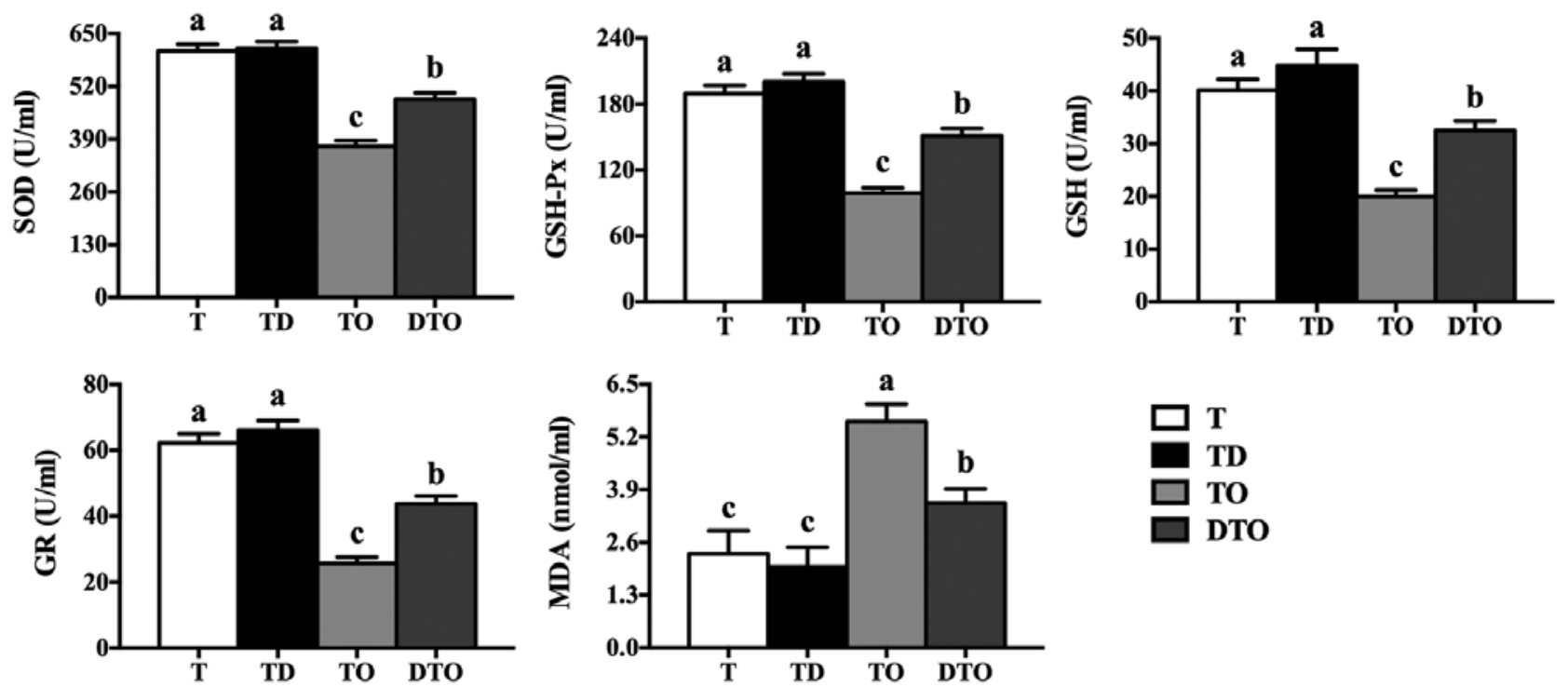

Figure 4. Effects of DMG-Na on the antioxidant capacity of OAHPx-damaged IPEC-J2 cell lysates. The experiment was repeated three times, and six repetitions per group. Values are presented as the mean \pm standard error. Groups with different letters were significantly different to each other $(\mathrm{P}<0.05)$. OAHPx, oleic acid hydroperoxides; T, PBS group; TD, $32 \mu \mathrm{M}$ DMG-Na; TO, $20 \mu \mathrm{M}$ OAHPx; DTO, $32 \mu \mathrm{M}$ DMG-Na followed by $20 \mu \mathrm{M}$ OAHPx; SOD, superoxide dismutase; GSH-Px, glutathione peroxidase; GSH, glutathione; GR, glutathione reductase; MDA, malondialdehyde.

the mean \pm standard error. $\mathrm{P}<0.05$ was considered to indicate a statistically significant different.

\section{Results}

Free radicals scavenging capacity of $\mathrm{DMG}-\mathrm{Na}$. The free radical scavenging capacity of the water-soluble pigments (DMG-Na, betalain, capsanthin and cyanidin-3-rutinoside) in comparison to that of the synthetic antioxidant Trolox is presented in Fig. 1. The free radical scavenging capacity of DMG-Na was measured relative to Trolox, which was set as $100 \%$ at all concentrations measured (from 0.08-0.64 M). DMG-Na exhibited the highest free radical scavenging capacity (DPPH, ABTS ${ }^{+}, \mathrm{O}_{2}^{-}, \mathrm{H}_{2} \mathrm{O}_{2}$ and
FRAP) at a concentration of $0.32 \mathrm{M}$, from the concentrations of 0.08-0.64 $\mathrm{M}$ that were tested.

Hemolysis and antioxidant system of porcine erythrocytes. Fig. 2 demonstrates the effects of DMG-Na on porcine erythrocytes exposed to the water-soluble radical initiator AAPH. When AAPH was added to the suspension, hemolysis induction increased in a time-dependent manner. DMG-Na prevented hemolysis in AAPH-challenged erythrocytes $(\mathrm{P}<0.05)$. As demonstrated in Fig. 2, DMG-Na protected the porcine erythrocytes from AAPH damage by increasing the cellular antioxidant enzyme activity $(\mathrm{P}<0.05)$ while inhibiting intracellular MDA and ROS formation $(\mathrm{P}<0.05)$. 

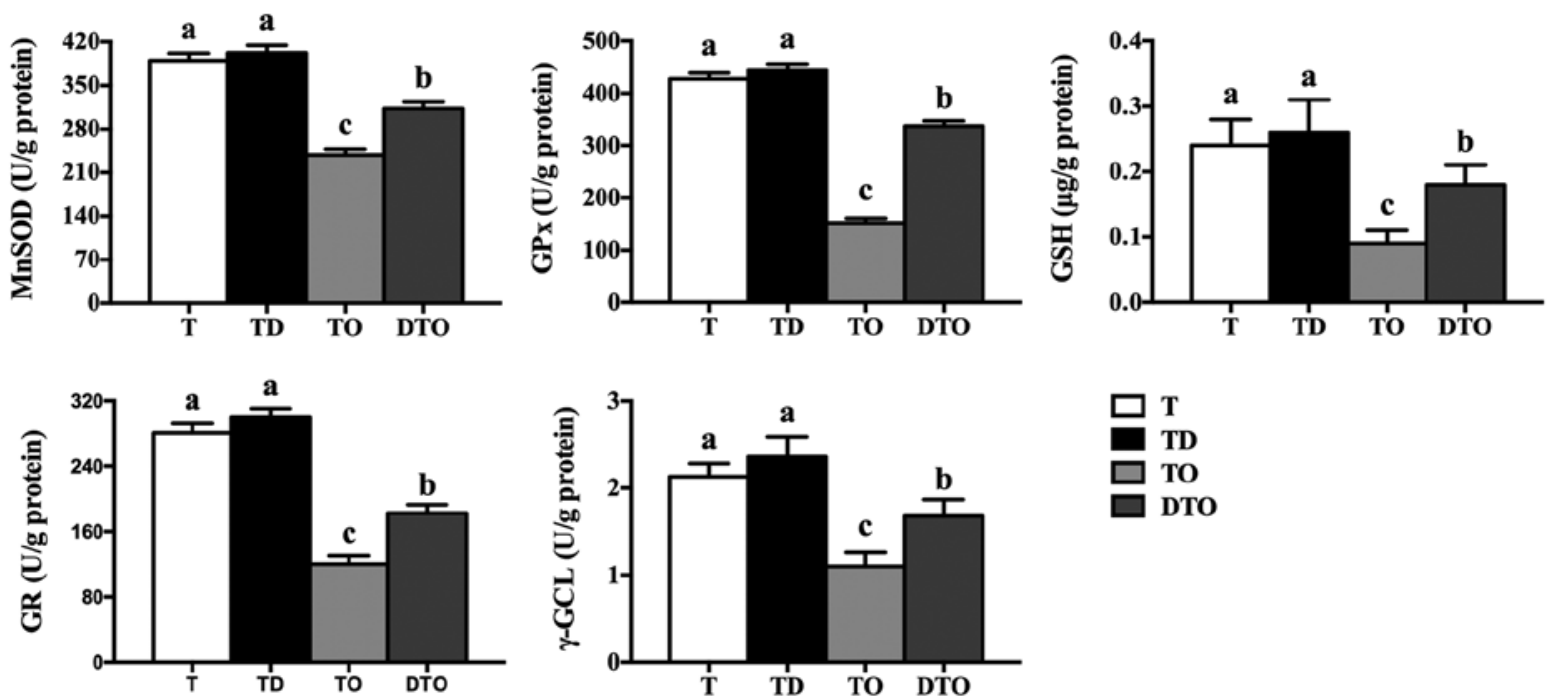

Figure 5. Effects of DMG-Na on the mitochondrial antioxidant capacity of OAHPx-damaged IPEC-J2 cells. The experiment was repeated three times, and six repetitions per group. Values are presented as the mean \pm standard error. Groups with different letters were significantly different to each other $(\mathrm{P}<0.05)$ OAHPx, oleic acid hydroperoxides; T, PBS group; TD, $32 \mu \mathrm{M}$ DMG-Na; TO, $20 \mu \mathrm{M}$ OAHPx; DTO, $32 \mu \mathrm{M}$ DMG-Na followed by $20 \mu \mathrm{M}$ OAHPx; MnSOD, manganese superoxide dismutase; GPx, glutathione peroxidase; GSH, glutathione; GR, glutathione reductase; $\gamma$-GCL, $\gamma$-glutamylcysteine ligase.
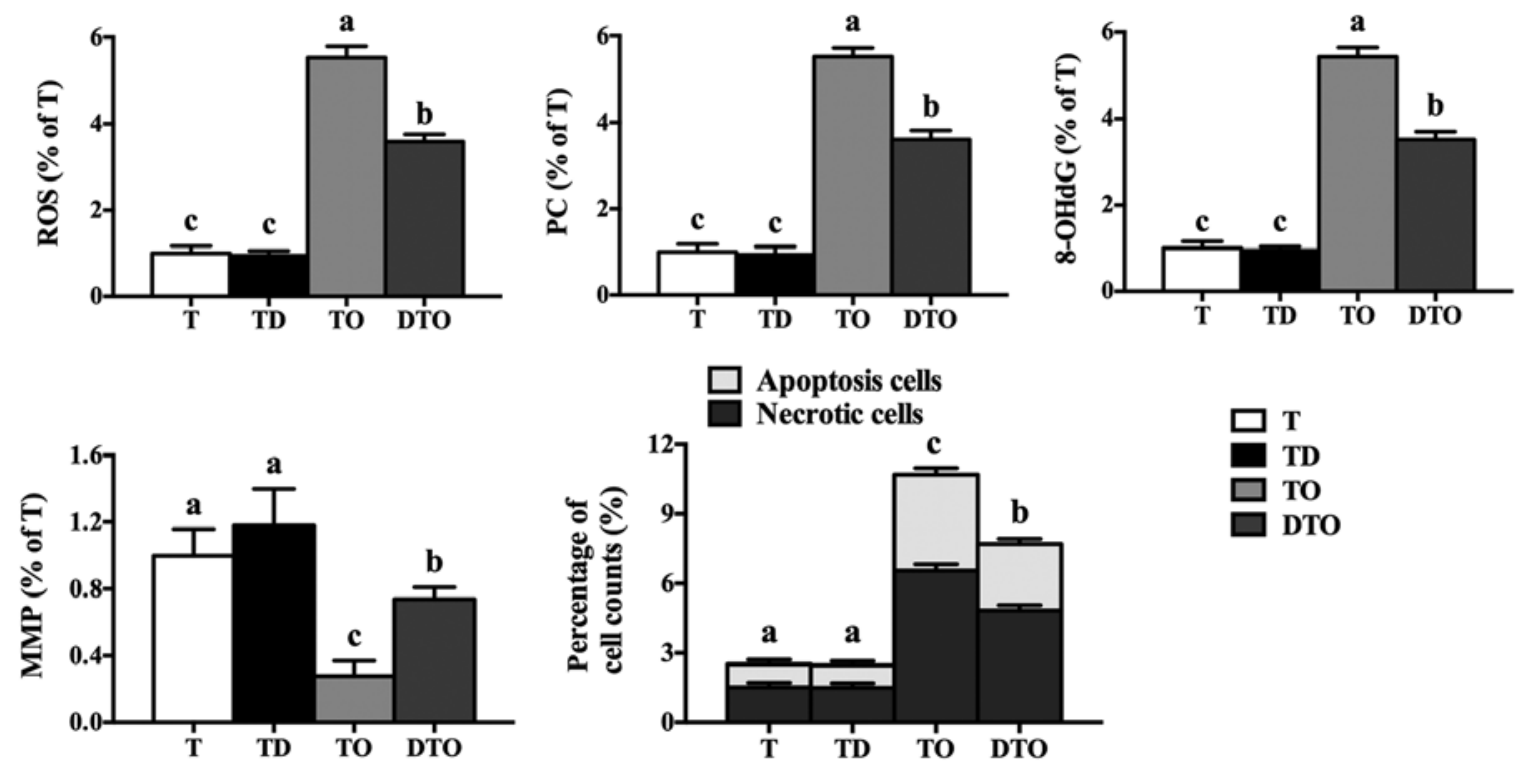

Figure 6. Effects of DMG-Na on the oxidative damage of OAHPx-damaged IPEC-J2 cells. The experiment was repeated three times, and six repetitions per group. Values are presented as the mean \pm standard error. Groups with different letters were significantly different to each other $(\mathrm{P}<0.05)$. OAHPx, oleic acid hydroperoxides; T, PBS group; TD, $32 \mu \mathrm{M}$ DMG-Na; TO, $20 \mu \mathrm{M}$ OAHPx; DTO, $32 \mu \mathrm{M}$ DMG-Na followed by $20 \mu \mathrm{M}$ OAHPx; ROS, reactive oxygen species; $\mathrm{PC}$, protein carbonyls; 8-OHdG, 8-hydroxy-2-deoxyguanosine; MMP, mitochondrial membrane potential.

Antioxidant system of IPEC-J2 cells. The effects of DMG-Na on the antioxidant capacity (SOD, GSH-Px, GSH, GR and MDA) of IPEC-J2 cells are presented in Figs. 3 and 4. The culture supernatant and cell lysate in the DTO group had greater antioxidant enzyme levels $(\mathrm{P}<0.05)$ and lower MDA concentrations in comparison to those in the TO group $(\mathrm{P}<0.05)$. Compared with the TO group, the DTO group also exhibited increased enzyme activity of MnSOD, GPx, GSH, GR and $\gamma$-GCL $(\mathrm{P}<0.05$; Fig. 5).

The effect of DMG-Na on the oxidative damage (ROS, PC, 8-OHdG, MMP, apoptosis and necrosis level) of IPEC-J2 cells is presented Fig. 6. Compared with the TO group, the DTO group exhibited lower ROS, PC, 8-OHdG, apoptosis and necrosis levels $(\mathrm{P}<0.05)$, along with higher MMP levels $(\mathrm{P}<0.05)$.

Anti-oxidant gene and protein expression in IPEC-J2 cells. The effects of DMG-Na on gene expression levels in IPEC-J2 cells are demonstrated in Fig. 7. Compared with the TO group, the DTO group exhibited greater levels of the genes copper and zinc superoxide dismutase, GSH-Px, MnSOD, Sirt1, $\gamma$-GCLc, $\gamma$-GCLm, thioredoxin 2 (Trx2), thioredoxin reductase 2 (Trx-R2), peroxiredoxin 3 (Prx3), occludin (OCLN) and zonula occludens- 1 ( $\mathrm{ZO1} ; \mathrm{P}<0.05)$, and lower levels of the genes Nrf2, HO-1, claudin 2 and claudin $3(\mathrm{P}<0.05)$. The DTO group also exhibited a higher protein level of Sirt1 $(\mathrm{P}<0.05)$, 

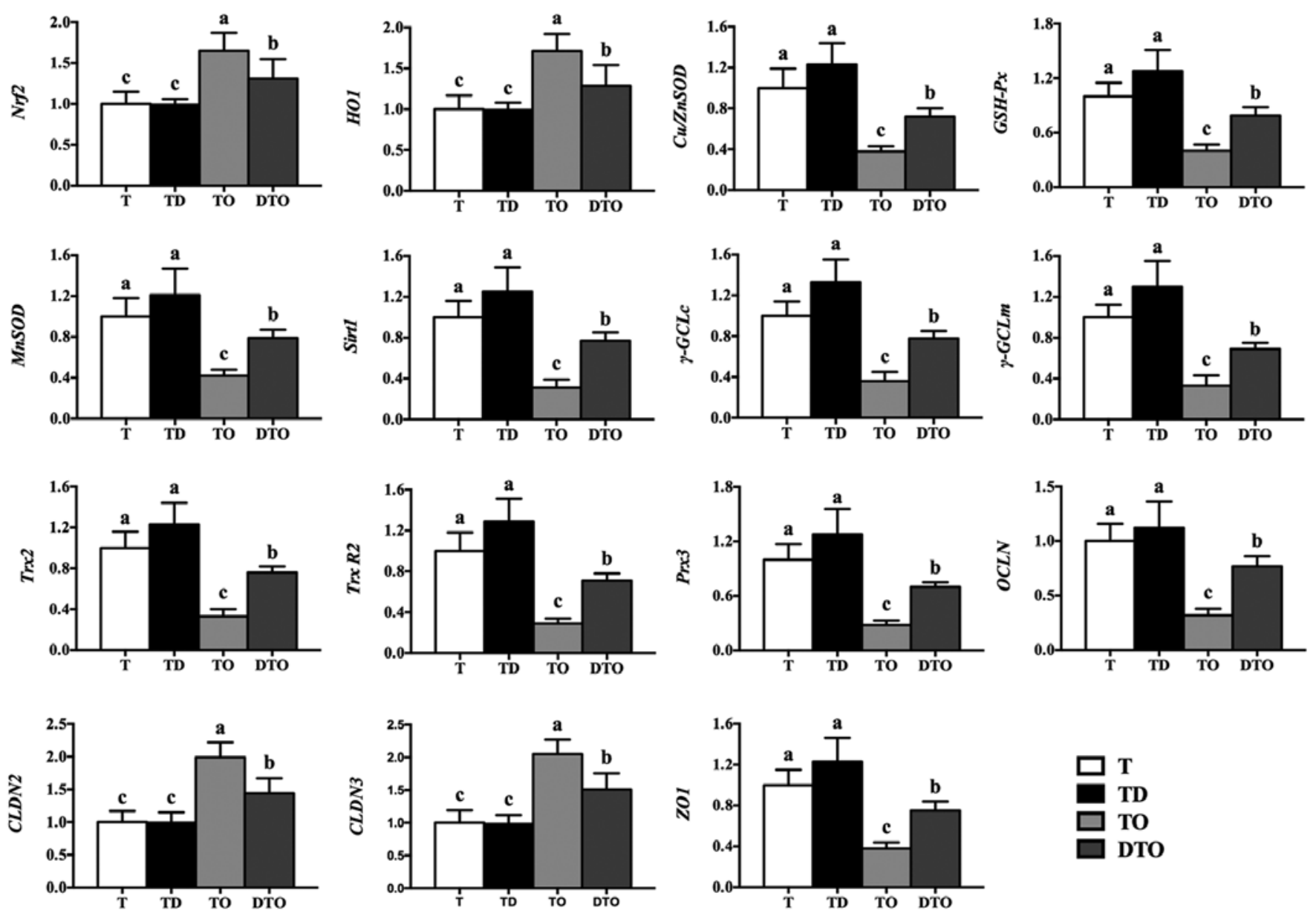

Figure 7. Effects of DMG-Na on gene expression in OAHPx-damaged IPEC-J2 cells. The experiment was repeated three times, and six repetitions per group. Values are presented as the mean \pm standard error. Groups with different letters were significantly different to each other $(\mathrm{P}<0.05)$. OAHPx, oleic acid hydroperoxides; T, PBS group; TD, $32 \mu \mathrm{M}$ DMG-Na; TO, $20 \mu \mathrm{M}$ OAHPx; DTO, $32 \mu \mathrm{M}$ DMG-Na followed by $20 \mu \mathrm{M}$ OAHPx; Nrf2, nuclear factor erythroid 2-related factor 2; $H O 1$, heme oxygenase 1; $\mathrm{Cu} / \mathrm{ZnSOD}$, copper and zinc superoxide dismutase; GSH-Px, glutathione peroxidase; $M n S O D$, manganese superoxide dismutase; Sirt1, sirtuin 1; $\gamma$-GCLc, $\gamma$-glutamylcysteine ligase c; $\gamma$-GCLm, $\gamma$-glutamylcysteine ligase m; Trx2, thioredoxin 2; Trx-R2, thioredoxin reductase 2; Prx3, peroxiredoxin 3; OCLN, occludin; CLDN2, claudin 2; CLDN3, claudin 3; ZO1, zonula occludens-1.

and lower $(\mathrm{P}<0.05)$ levels of the proteins $\mathrm{Nrf} 2$ and $\mathrm{HO}-1$ compared with the TO group (Fig. 8).

\section{Discussion}

DPPH and $\mathrm{ABTS}^{+}$radicals have excellent reproducibility and stability, and for these reasons, are the two chromogenic compounds most commonly used to determine the capacity of a compound to inhibit free radicals. Reaction with the antioxidant DPPH neutralizes excess free radicals by transferring either an electron or a hydrogen atom (33). The $\mathrm{ABTS}^{+}$decolorization assay is used for the rapid measurement of the total antioxidant activity of individual chemical compounds (34). In the case of cellular oxidation reactions, $\mathrm{O}_{2}{ }^{-}$and $\mathrm{H}_{2} \mathrm{O}_{2}$ are two of the most common free radicals produced, that then produce other cell-damaging free radicals and oxidizing agents in vivo $(35,36)$. Of all the antioxidant capacity detection assays, the FRAP assay is the only one that directly measures antioxidants in samples and is useful in the measurement of oxidative damage (37). In the present study, Trolox was used as a standard substance that exerts strong free radical scavenging capacity in vitro. DMG-Na exhibited the greatest free radical scavenging activity at a concentration of $0.32 \mathrm{M}$, indicating the potential of DMG-Na as a free radical scavenger. Similar to our results, Hariganesh and Prathiba (2) reported the free radical scavenging potential of orally-administered DMG-Na in rats subjected to oxidative stress. As DMG-Na exerts a strong free radical scavenging capacity in vitro, whether DMG-Na could prevent oxidative damage in a cell model was assessed in the current study.

Based on the results of free radical scavenging assays, DMG-Na was selected for further evaluation of its protective effect against hemolysis in AAPH-challenged porcine erythrocytes. Erythrocytes possess a high membrane concentration of polyunsaturated fatty acids, have a specific role as oxygen carriers and are considered to be the major targets for free radical attacks (38). In the present study, DMG-Na prevented AAPH-induced hemolysis of erythrocyte membranes. It has been reported that DMG, a raw material used in the synthesis of glutathione, is an important antioxidant that can protect the body from oxidative damage (1). Thus, the powerful protection of DMG-Na against AAPH-induced hemolysis in the porcine erythrocyte model may be explained by its strong free radical scavenging capacity. Erythrocyte membrane lipids can lose a hydrogen atom from an unsaturated fatty acyl chain when they are subjected to oxidative damage (39). 

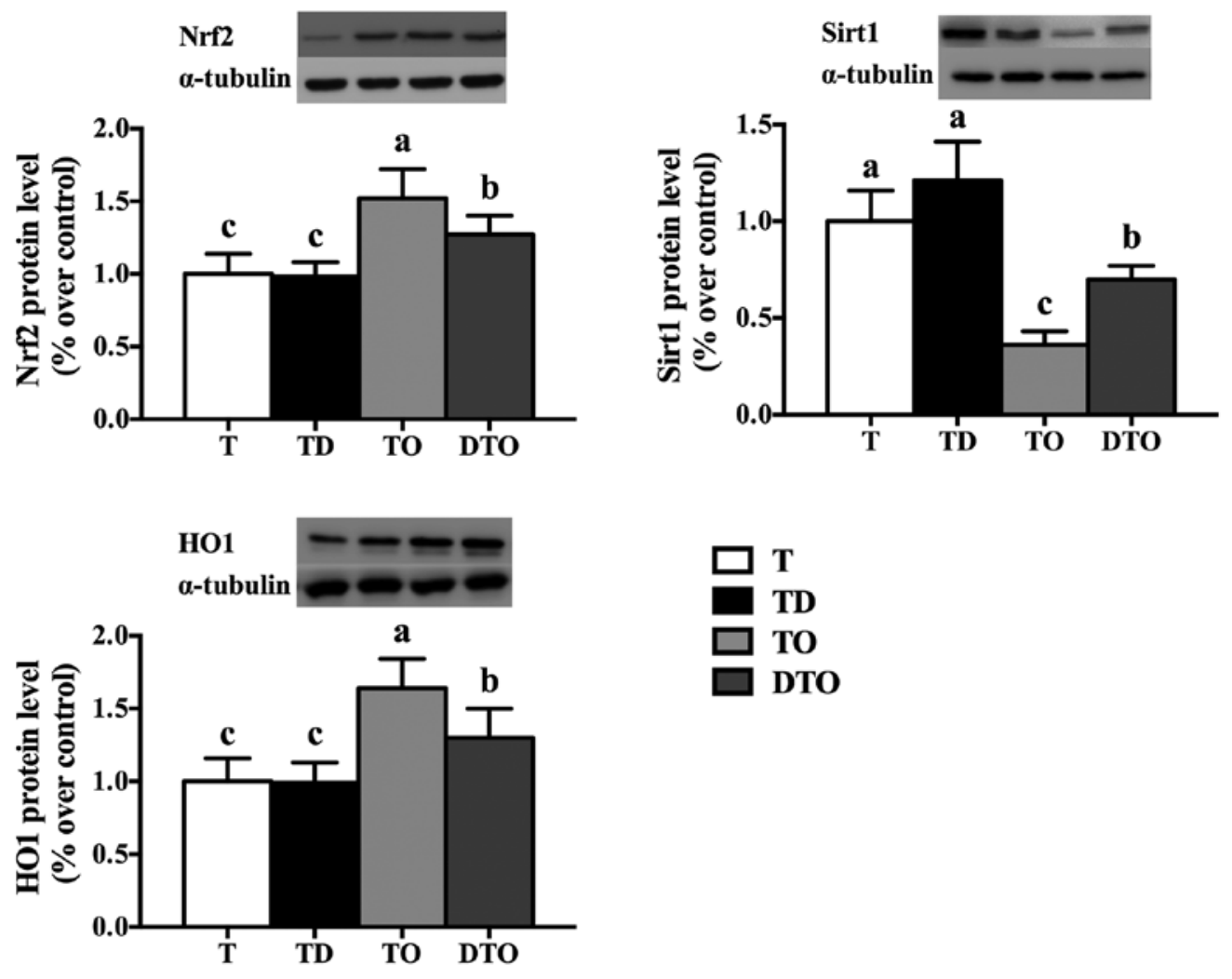

Figure 8. Effects of DMG-Na on Nrf2, HO1, and Sirt1 protein level of OAHPx-damaged IPEC-J2 cells. The experiment was repeated three times, and six repetitions per group. Values are presented as the mean \pm standard error. Groups with different letters were significantly different to each other $(\mathrm{P}<0.05)$. OAHPx, oleic acid hydroperoxides; T, PBS group; TD, $32 \mu \mathrm{M}$ DMG-Na; TO, $20 \mu \mathrm{M}$ OAHPx; DTO, $32 \mu \mathrm{M}$ DMG-Na followed by $20 \mu \mathrm{M}$ OAHPx; Nrf2, nuclear factor erythroid 2-related factor 2; Sirt1, sirtuin 1; HO1, heme oxygenase 1.

This step initiates lipid peroxidation, which then propagates as a chain reaction. Oxidative damage can destroy the lipid bilayer membrane structure, alter membrane permeability, disrupt ion channels and ultimately lead to dysfunction of whole erythrocytes (40). In erythrocytes, oxidative damage induced by free radicals can be prevented by the SOD enzyme, which protects cells by dismutating the highly reactive $\mathrm{O}_{2}$ species to $\mathrm{H}_{2} \mathrm{O}_{2}$, which is then neutralized by GSH-Px and GSH $(41,42)$. These results are consistent with those reported by Deng et al (43) and Tedesco et al (44) that reported the protective roles of antioxidant substances against oxidative damage in human erythrocytes. The results of the present study suggest that DMG-Na exerted strong protective effects against lipid peroxidation and indicates that it could reduce the MDA and ROS levels in AAPH-challenged porcine erythrocytes. The present results provide strong evidence for DMG-Na application in oxidative damage-associated diseases; however, further study regarding the specific mechanisms involved is still required.

The small intestine is the main organ that digests and absorbs nutrients, and is the first line of defense against foreign pathogenic microorganisms and toxins. The ability of foreign substances to cross the cell membrane into intestinal cells depends on either diffusion or active transport (45). Oxidative damage is caused by enhanced levels of ROS, which can destroy the mitochondrial structure and decrease antioxidant capacity. Previous studies have indicated that DMG is an important antioxidant that can prevent oxidative damage in the body by scavenging excess free radicals (1). In cells, oxidative damage induced by free radicals can be prevented by the enzyme, SOD, which catalyzes the conversion of endogenous superoxide anions to hydrogen peroxide through disproportionation; hydrogen peroxide is then neutralized by the intracellular GSH-Px enzyme (41). The mitochondrial antioxidant system is composed of enzymatic and non-enzymatic antioxidants that protect the body from oxidative damage (46). It has been reported that the MnSOD enzyme and GSH-associated metabolic enzymes are important members of the mitochondrial antioxidant system and are crucial in suppressing oxidative damage by neutralizing excess ROS and acting as a substrate for various other antioxidant enzymes (27). $\gamma$-GCL is an important rate-limiting enzyme that is involved in the synthesis of $\gamma$-glutamylcysteine and is crucial for relieving oxidative damage (28). A previous study reported that DMG-Na acts as an important component in relieving oxidative damage by enhancing antioxidant capacity $(1,47)$. Results from the present study suggest that DMG-Na may improve the total antioxidant capacity by scavenging excess ROS, so as to maintain the intracellular redox balance.

When oxidative damage occurs, the blockade of oxidative phosphorylation reactions can increase the levels of ROS (48). The excess ROS harms biological macromolecular substances, and exacerbates the oxidative damage through lipid peroxidation and protein oxidation reactions (49). Mitochondria are also prone to becoming damaged by the excess ROS (50). This information is supported by the findings of the present study, where the damaged IPEC-J2 cells exhibited higher concentrations of MDA, PC, $8-\mathrm{OHdG}$ and ROS compared 
with those in the T group. It has been reported that DMG, a natural antioxidant, can effectively neutralize free radicals to alleviate oxidative damage in the body (2). It was hypothesized that pre-treatment with DMG-Na could minimize lipid peroxidation and protein oxidation reactions by scavenging excess ROS in cells. MMP expression is negatively associated with ROS concentration, and acts as an indicator for the beginning of mitochondria-dependent apoptosis. When MMP levels are reduced, there is uncoupling of oxidative phosphorylation in the mitochondria, which results in an increase in ROS levels and inevitably leads to apoptosis (46). The present study indicates that the administration of DMG-Na may lead to relief of oxidative damage. This is supported by previous studies demonstrating that natural antioxidants could inhibit apoptosis by protecting cells from oxidative damage $(1,51)$. We hypothesize that there is a correlation between the anti-apoptotic effect of DMG-Na and the protective effects of DMG-Na on mitochondrial function in damaged IPEC-J2 cells; however, further study is still required.

The activation of the genes $\mathrm{Nrf2,HO-1}$ and SIRTI is important in relieving oxidative damage, and is also crucial in regulating the gene expressions of certain important antioxidant enzymes (52-55). Mitochondria are rich in Trx2, Trx-R2 and Prx3, which together compose a unique antioxidant system that prevents oxidative stress by scavenging free radicals and regulating mitochondrial-dependent apoptotic pathways (56). The gene $\mathrm{ZOI}$ is correlated with paracellular permeability, and together with the genes $O C L N$ and CLDN from the same gene family, it is a key regulator of intestinal permeability (57). A previous study suggested that a natural antioxidant was beneficial in the regulation of antioxidant-associated gene expression (47,51). The current study indicated that the regulation of antioxidant-associated genes may be one mechanism used by IPEC-J 2 cells to prevent oxidative stress and maintain mitochondrial function.

The present study indicates that DMG-Na is a strong free radical quencher. Furthermore, DMG-Na reduced lipid peroxidation, increased antioxidant enzyme activity and attenuated hemolysis in AAPH-challenged porcine erythrocytes. The present study also demonstrated that DMG-Na effectively prevented the oxidative damage of IPEC-J2 cells by scavenging excess ROS, preventing mitochondrial dysfunction and inhibiting cell apoptosis. Based on these results, it is speculated that DMG-Na may directly neutralize excess free radicals, and act indirectly on the improvement of antioxidant enzyme activity and inhibit the abnormal expression of stress-associated factors.

\section{Acknowledgements}

Not applicable

\section{Funding}

No funding was received.

\section{Availability of data and materials}

The datasets used and/or analyzed during the current study are available from the corresponding author on reasonable request.

\section{Authors' contributions}

$\mathrm{KB}$ and LJ analyzed and interpreted the IPEC- J2 cell data. KB, LigenZ, YZ, YL, JZ, JC, LiliZ and TW performed the whole experiment, and LJ was a major contributor in writing the manuscript. All authors read and approved the final manuscript.

\section{Ethics approval and consent to participate}

All procedures were approved by the Institutional Animal Care and Use Committee of Nanjing Agricultural University (Nanjing, China)

\section{Patient consent for publication}

Not applicable.

\section{Competing interests}

The authors declare that they have no competing interests.

\section{References}

1. Friesen RW, Novak EM, Hasman D and Inniset SM: Relationship of dimethylglycine, choline, and betaine with oxoproline in plasma of pregnant women and their newborn infants. J Nutr 137: 2641-2646, 2007.

2. Hariganesh K and Prathiba J: Effect of dimethylglycine on gastric ulcers in rats. J Pharm Pharmacol 52: 1519-1522, 2000.

3. Clapes P and Infante MR: Amino acid-based surfactants: Enzymatic synthesis, properties and potential applications. J Biocatalys Biotransformation 20: 215-233, 2002.

4. Giacco F and Brownlee M: Oxidative stress and diabetic complications. Circ Res 107: 1058-1070, 2010.

5. Grune T: Oxidative stress, aging and the proteasomal system. Biogerontology 1: 31-40, 2000.

6. Ma K, Zhang Y, Zhu D and Lou Y: Protective effects of asiatic acid against D-galactosamine/lipopolysaccharide-induced hepatotoxicity in hepatocytes and kupffer cells co-cultured system via redox-regulated leukotriene $\mathrm{C} 4$ synthase expression pathway. Eur J Pharmacol 603: 98-107, 2009.

7. Balaban RS, Nemoto S and Finkel T: Mitochondria, oxidants, and aging. Cell 120: 483, 2005

8. Andreyev AY, Kushnareva YE and Starkov AA: Mitochondrial metabolism of reactive oxygen species. Biochemistry (Mosc) 70: 200-214, 2005.

9. Dong L, Zhong X, He J, Zhang L, Bai K, Xu W, Wang T and Huang X: Supplementation of tributyrin improves the growth and intestinal digestive and barrier functions in intrauterine growth-restricted piglets. Clin Nutr 35: 399-407, 2016.

10. Inoue J, Miki I, Tanahashi T, Kawauchi S, Azuma $T$ and Mizuno S: Mo2016 effect of ghrelin on indomethacin-induced small intestinal injury in mice. Gastroenterology 144: S-719, 2013.

11. Konaka A, Kato S, Tanaka A, Kunikata T, Korolkiewicz R and Takeuchi K: Roles of enterobacteria, nitric oxide and neutrophil in pathogenesis of indomethacin-induced small intestinal lesions in rats. Pharmacol Res 40: 517-524, 1999.

12. Liu F, Li G, Wen K, Bui T, Cao D, Zhang Y and Yuan L: Porcine small intestinal epithelial cell line (IPEC-J2) of rotavirus infection as a new model for the study of innate immune responses to rotaviruses and probiotics. Viral Immunol 23: 135-149, 2010.

13. Brosnahan AJ and Brown DR: Porcine IPEC-J2 intestinal epithelial cells in microbiological investigations. Vet Microbiol 156: 229-237, 2012.

14. Arce C,Ramírez-Boo M,Lucena C and Garrido JJ: Innate immune activation of swine intestinal epithelial cell lines (IPEC-J2 and IPI-2I) in response to LPS from salmonella typhimurium. Comp Immunol Microbiol Infect Dis 33: 161-174, 2010.

15. Moon JK and Shibamoto T: Antioxidant assays for plant and food components. J Agric Food Chem 57: 1655-1666, 2009. 
16. Siddhuraju P and Manian S: The antioxidant activity and free radical-scavenging capacity of dietary phenolic extracts from horse gram (Macrotyloma uniflorum (Lam.) Verdc.) seeds. Food Chem 105: 950-958, 2007.

17. Chen HY and Yen GC: Antioxidant activity and free radical-scavenging capacity of extracts from guava (Psidium guajava L.) leaves. Food Chem 101: 686-694, 2007.

18. Zhang J, Hou X, Ahmad H, Zhang H, Zhang L and Wang T: Assessment of free radicals scavenging activity of seven natural pigments and protective effects in AAPH-challenged chicken erythrocytes. Food Chem 145: 57-65, 2014

19. Benzie IF and Strain JJ: The ferric reducing ability of plasma (FRAP) as a measure of 'antioxidant power': The frap assay. Anal Biochem 239: 70-76, 1996.

20. Magalhães AS, Silva BM, Pereira JA, Andrade PB, Valentão P and Carvalho M: Protective effect of quince (cydonia oblonga miller) fruit against oxidative hemolysis of human erythrocytes Food Chem Toxicol 47: 1372-1377, 2009.

21. Lawrence RA and Burk RF: Glutathione peroxidase activity in selenium-deficient rat liver. Biochem Biophys Res Commun 71: 952-958, 1976

22. Panchenko LF, Brusov OS, Gerasimov AM and Loktaeva TD Intramitochondrial localization and release of rat liver superoxide dismutase. FEBS Lett 55: 84-87, 1975.

23. SangH,ZhangLandLiJ: Anti-benzopyrene-7,8-diol-9,10-epoxide induces apoptosis via mitochondrial pathway in human bronchiolar epithelium cells independent of the mitochondria permeability transition pore. Food Chem Toxicol 50: 2417-2423, 2012.

24. AOAC: Official Methods of Analysis. 14th edition. Association of Official Analytical Chemists, Washington, DC, 1985.

25. Aw TY, Williams MW and Gray L: Absorption and lymphatic transport of peroxidized lipids by rat small intestine in vivo: Role of mucosal GSH. Am J Physiol 262: G99-G106, 1992.

26. Repetto G, Peso AD and Zurita JL: Neutral red uptake assay for the estimation of cell viability/cytotoxicity. Nat Protoc 3 : $1125-1131,2008$

27. Tang X, Gao J, Wang Y, Fan YM, Xu LZ, Zhao XN, Xu Q and Qian ZM: Effective protection of terminalia catappa 1. Leaves from damage induced by carbon tetrachloride in liver mitochondria. J Nutr Biochem 17: 177-182, 2006.

28. Langston JW, Li W, Harrison L and Aw TY: Activation of promoter activity of the catalytic subunit of $\gamma$-glutamylcysteine ligase (GCL) in brain endothelial cells by insulin requires antioxidant response element 4 and altered glycemic status: Implication for GCL expression and GSH synthesis. Free Radic Biol Med 51: 1749-1757, 2011.

29. Van Remmen H, Ikeno Y, Hamilton M, Pahlavani M, Wolf N, Thorpe SR, Alderson NL, Baynes JW, Epstein CJ, Huang TT, et al: Life-long reduction in MnSOD activity results in increased DNA damage and higher incidence of cancer but does not accelerate aging. Physiol Genomics 16: 29-37, 2003.

30. Wei QY, Chen WF, Zhou B, Yang L and Liu ZL: Inhibition of lipid peroxidation and protein oxidation in rat liver mitochondria by curcumin and its analogues. Biochim Biophys Acta 1760 : 70-77, 2006

31. Zhang Q, Zou P, Zhan H, Zhang M, Zhang L, Ge RS and Huang Y: Dihydrolipoamide dehydrogenase and cAMP are associated with cadmium-mediated leydig cell damage. Toxicol Lett 205: 183-189, 2011

32. Livak KJ and Schmittgen TD: Analysis of relative gene expression data using real-time quantitative pcr and the 2(-Delta Delta C(T)) method. Methods 25: 402-408, 2001.

33. Naik GH, Priyadarsini KI, Satav JG, Banavalikar MM, Sohoni DP, Biyani MK and Mohan H: Comparative antioxidant activity of individual herbal components used in ayurvedic medicine. Phytochemistry 63: 97-104, 2003.

34. JiSang K and YoungSoon L: Antioxidant activity of Maillard reaction products derived from aqueous glucose/glycine, diglycine, and triglycine model systems as a function of heating time. Food Chem 116, 227-232, 2009.

35. Rollet-Labelle E, Grange MJ, Elbim C, Marquetty C, Gougerot-Pocidalo MA and Pasquier C: Hydroxyl radical as a potential intracellular mediator of polymorphonuclear neutrophil apoptosis. Free Radic Biol Med 24: 563-572, 1998

36. Wang J, Yuan X, Jin Z, Tian Y and Song H: Free radical and reactive oxygen species scavenging activities of peanut skins extract. Food Chem 104, 242-250, 2007.
37. Bernaert N, De Paepe D, Bouten C, De Clercq H, Stewart D, Van Bockstaele E, De Loose M and Van Droogenbroeck B: Antioxidant capacity, total phenolic and ascorbate content as a function of the genetic diversity of leek (Allium ampeloprasum var. porrum). Food Chem 134: 669-677, 2012

38. Ajila CM and Prasada Rao UJ: Protection against hydrogen peroxide induced oxidative damage in rat erythrocytes by mangifera indica L. peel extract. Food Chem Toxicol 46 303-309, 2008.

39. Mendes L, de Freitas V, Baptista P and Carvalho M: Comparative antihemolytic and radical scavenging activities of strawberry tree (Arbutus unedo L.) leaf and fruit. Food Chem Toxicol 49: 2285-2291, 2011.

40. Lang F, Lang KS, Lang PA, Huber SM and Wieder T: Mechanisms and significance of eryptosis. Antioxid Redox Signal 8: 1183-1192, 2006.

41. Bayrak O, Uz E, Bayrak R, Turgut F, Atmaca AF, Sahin S, Yildirim ME, Kaya A, Cimentepe E and Akcayet A: Curcumin protects against ischemia/reperfusion injury in rat kidneys. World J Urol 26: 285-291, 2008.

42. Forman HJ, Zhang H and Rinna A: Glutathione: Overview of its protective roles, measurement, and biosynthesis. Mol Aspects Med 30: 1-12, 2009.

43. Deng SL, Chen WF, Zhou B, Yang L and Liu ZL: Protective effects of curcumin and its analogues against free radical-induced oxidative haemolysis of human red blood cells. Food Chem 98: $112-119,2006$

44. Tedesco I, Luigi Russo G, Nazzaro F, Russo M and Palumbo R: Antioxidant effect of red wine anthocyanins in normal and catalase-inactive human erythrocytes. J Nutr Biochem 12: 505-511, 2001.

45. Nusrat A, Parkos CA, Verkade P, Foley CS, Liang TW, Innis-Whitehouse W, Eastburn KK and Madara JL: Tight junctions are membrane microdomains. J Cell Sci 113: 1771-1781, 2000.

46. Kowaltowski AJ and Vercesi AE: Mitochondrial damage induced by conditions of oxidative stress. Free Radic Biol Med 26: 463-471, 1999.

47. Bai K, Xu W, Zhang J, Kou T, Niu Y, Wan X, Zhang L, Wang C and Wang T: Assessment of free radical scavenging activity of dimethylglycine sodium salt and its role in providing protection against lipopolysaccharide-induced oxidative stress in mice. PLoS One 11: e0155393, 2016.

48. Lee HJ, Oh YK, Rhee M, Lim JY, Hwang JY, Park YS, Kwon Y, Choi KH, Jo I, Park SI, et al: The role of STAT1/IRF-1 on synergistic ROS production and loss of mitochondrial transmembrane potential during hepatic cell death induced by LPS/d-GalN. J Mol Biol 369: 967-984, 2007.

49. Wilhelm EA, Jesse CR, Roman SS, Nogueira CW and Savegnago L: Hepatoprotective effect of 3-alkynyl selenophene on acute liver injury induced by D-galactosamine and lipopolysaccharide. Exp Mol Pathol 87: 20-26, 2009.

50. Chen JJ and Yu BP: Alterations in mitochondrial membrane fluidity by lipid peroxidation products. Free Radic Biol Med 17: 411-418, 1994.

51. Zhang J, Xu L, Zhang L, Ying Z, Su W and Wang T: Curcumin attenuates D-galactosamine/lipopolysaccharide-induced liver injury and mitochondrial dysfunction in mice. J Nutr 144: 1211-1218, 2014.

52. Chiu H, Brittingham JA and Laskin DL: Differential induction of heme oxygenase-1 in macrophages and hepatocytes during acetaminophen-induced hepatotoxicity in the rat: Effects of hemin and biliverdin. Toxicol Appl Pharmacol 181: 106-115, 2002

53. Chung S, Yao H, Caito S, Hwang JW, Arunachalam G and Rahman I: Regulation of SIRT1 in cellular functions: Role of polyphenols. Arch Biochem Biophys 501: 79-90, 2010.

54. Hwang JW, Yao H, Caito S, Sundar IK and Rahman I: Redox regulation of SIRT1 in inflammation and cellular senescence. Free Radic Biol Med 61: 95-110, 2013.

55. Lee JM and Johnson JA: An important role of Nrf2-are pathway in the cellular defense mechanism. J Biochem Mol Biol 37: 139-143, 2004

56. Michelet L, Zaffagnini M, Massot V, Keryer E, Vanacker H, Miginiac-Maslow M, Issakidis-Bourguet E and Lemai SD: Thioredoxins, glutaredoxins, and glutathionylation: New crosstalks to explore. Photosynth Res 89: 225-245, 2006.

57. Gu L, Li N, Gong J, Li Q, Zhu W and Li J: Berberine ameliorates intestinal epithelial tight-junction damage and down-regulates myosin light chain kinase pathways in a mouse model of endotoxinemia. J Infect Dis 203: 1602-1612, 2011. 